\title{
BRAIN CELLS REACTION IN A RESPONSE TO ANTIGEN INJECTION IN ANIMALS EXPOSED TO ACUTE PRENATAL STRESS
}

\author{
P.S. Shakleina, N.S. Novikova \\ Institute of Experimental Medicine, Saint Petersburg, Russia
}

\section{РЕАКЦИЯ КЛЕТОК МОЗГА В ОТВЕТ НА ВВЕДЕНИЕ АНТИГЕНА У ЖИВОТНЫХ ПЕРЕНЕСШИХ ПРЕНАТАЛЬНЫЙ СТРЕСС}

\author{
П.С. Шаклеина, Н.С. Новикова
}

\author{
ФГБНУ «Институт экспериментальной медицины», Санкт-Петербург
}

Prenatal stress is one of the major cause of long-term disorders in behavioral and neuroimmunne processes. Emotional prenatal maternal stress (PRMS) performsin an offspring tendency to anxiety, depressive-like behavior and weakening memorizing skills. The study field was to determinate preproorexin gene expression of the maturity rats held in prenatal stress on the $19^{\text {th }}$ day. The expression level was measured in two hours after intravenous LPS injection. qPCR shoved significant reduction in preproorexin gene expression in hypothalamus cells. This result corresponds with behavioral tests where animals exposed to stress during the late term of in utero development demonstrate less motion search activity which allovers to suspect a connection between prenatal stress and incidences of psycho-neuro-immunne relationships disorders.

Keywords: stress; prenatal stress; maternal stress; preproorexin; LPS; antigen injection.

Пренатальный стресс является одной из основных причин долговременных нарушений в поведенческих реакциях и нейроиммунных процессах. Эмоциональный стресс во время беременности провоцирует формирование тенденций к тревожности, депрессивно-подобному поведению и снижению памяти. В данном исследовании предметом изучения являлось определение экспрессии гена препроорексина в мозге у взрослых крыс Вистар, перенесших пренатальный стресс. По результатам ПЦР установлено значительное снижение экспрессии гена препроорексина через два часа после в/в инъекции ЛПС. Данные результаты соотносятся с поведенческими тестами, в которых животные опытных групп, демонстрируют меньшую двигательную и поисковую активность, что позволяет предполагать связь между пренатальным стрессом с проявлением нарушений психонейроиммунных взаимодействий.

Ключевые слова: стресс; пренатальный стресс; материнский стресс; препроорексин; ЛПС; введение антигена.

Introduction. Prenatal development influences on functional abilities of an adult organism [2]. Emotional prenatal maternal stress (PRMS) during late pregnancy reflects in progeny through increasing anxiety level, depressive-like behavior and lower memorizing skills [3]. Restricted mobility is the most often used method to stimulate emotional stress in rodents. Hypothalamic neuropeptide orexin plays an important role in the pathophysiology of mental disorders, including depression [4]. Consequences of chronic emotional maternal stress have received wide coverage in many publications $[3,4]$ while acute impact is still not studied enough.

The purpose of this study was to determine hypothalamic preproorexin gene expression in a response to intravenous LPS injection from old rats stressed prenatally on $19^{\text {th }}$ day of intrauterine development.

Materials and methods. On the $19^{\text {th }}$ day of pregnancy, female rats were exposed to emotional stress through a restriction in a plastic tube for 20 minutes. Four months old male offspring were divided into two groups -13 reared in standard condition (subgroups 1 and 2), and 12 exposed to PRMS (subgroups 3 and 4). LPS (E. Coli 055:B5,
"Sigma", L2880) was injected into the tail vein in $500 \mathrm{mcl} / \mathrm{kg}$ dose (table).

Hypothalamus samples were taken in two hours after injection. "Aurum Total RNA Fatty and Fibrous Tissue Pack" (Bio-Rad) kit was used for mRNA isolation. Reverse transcription (RT) reaction was performed according to the standard protocol. Primer pairs for qPCRwere made by "Beagle": preproorexin (PPOx): sense 5'-TGTCGCCCAGAAGACGTGTTC CTG-3': antisense 5'-AAGACGGGTTCACACACTCTGG-ATC-3', annealing temperature $62^{\circ} \mathrm{C}$; G3PDH: sense 5'-CCACTCA-GAAGACTGTGGAT-3', antisense 5'-GTCATCATACTTGGCAGGTT-3', annealing temperature $55^{\circ} \mathrm{C} .10 \mathrm{mcliTaq}^{\mathrm{TM}}$ Universal $\mathrm{SYBR}^{\circledR}$ Green Supermix (BioRad) was used as reaction master. QPCR was performed by CFX384 Touch amplificatory. Gene expression level was majored to G3PDH gene by using $2^{-\Delta \Delta \mathrm{Cq}}$ method. Data were analyzed by U-criterion. QPCR products were identified by melt curves analyze.

Results. According to qPCR results, control animals have a significantly higher level of PPO gene expression in two hours after LPS intravenous injection which have a confirmation 
Animals' groups

\begin{tabular}{|c|c|c|c|c|c|}
\hline Name & Groups of animals & Number of animals & Injected substance & $\begin{array}{c}\text { Average weight } \\
\text { of the animals }\end{array}$ & $\begin{array}{c}\text { Injected solution's volume/ } \\
\text { concentration }\end{array}$ \\
\hline Subgroup 1 & Control & 6 & Saline solution & 396 & $200 \mathrm{mcl}$ \\
\hline Subgroup 2 & Control & 7 & LPS & 392 & $200 \mathrm{mcl} / 500 \mathrm{mcg} / \mathrm{kg}$ \\
\hline Subgroup 3 & PRMS & 6 & Saline solution & 420.5 & $200 \mathrm{mcl}$ \\
\hline Subgroup 4 & PRMS & 6 & LPS & 443.5 & $200 \mathrm{mcl} / 500 \mathrm{mcg} / \mathrm{kg}$ \\
\hline
\end{tabular}

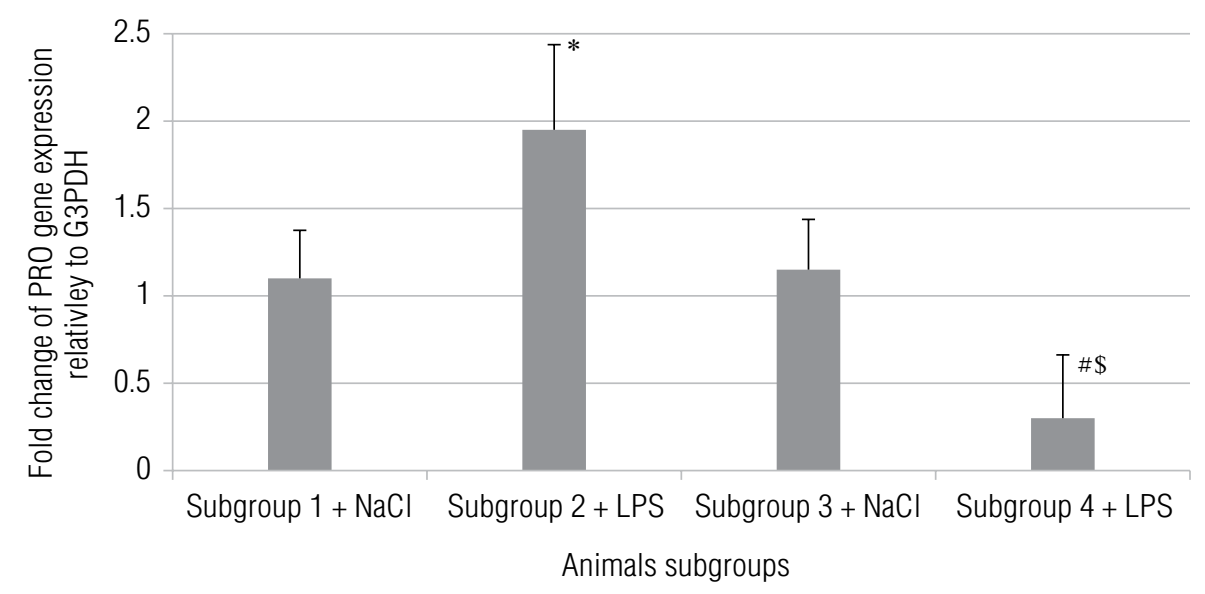

Fig. PPO gene expression level of adult male Wistar rats exposed to prenatal stress. ${ }^{*} p<0.05$, compared with subgroup 1 ; ${ }^{\#, \$} p<0.05$, compared with subgroups 2 and 3

in publications [5]. It has been observed that in PRMS group, in two hours after intravenous LPS injection, the level of PPO gene expression was reliable lower compare to subgroups 2 and 3 (Figure).

Discussion. In adults animals stressed prenatally during lateterm of intrauterine development was defined lover searching activity and stress tolerance compare to animals reared in standard condition. Previously collected data [1] and the results of this study demonstrate that it is possible to assume connection between decreasing level of PPO gene expression in neurons in a response to antigen introduction and stress tolerance.

Conclusion. From the literature and own outcomes must be assumed that prenatal stress during late pregnancy manifests itself in an adult offspring in a disruption of neuroimmune interactions.

\section{References}

1. Шаклеина П.С. Влияние острого пренатального стресса на показатели стрессоустойчивости у взрослых самцов крыс породы Wistar // Материалы Международного молодежного научного форума «Ломоносов-2018» [Электронный ресурс]. - М.: MAKC Пресс, 2018, 1 электрон. опт. диск (DVD-ROM).

2. Harris A, Seckl J. Glucocorticoids, prenatal stress and the programming of disease. HormBehav. 2011;59(3):279-89. https://doi.org/10.1016/j.yhbeh.2010.06.007.

3. Arriagada-Solimano M, Luttecke-Anders A, Dagnino-Subiabre A, Iturra-Mena AM. Effects of prenatal stress on anxiety- and depressive-like behaviours are sex-specific in prepubertal rats. J. Neuroendocrinol. 2018;30(7):e12609. https://doi.org/10.1111/jne.12609.

4. Ji MJ, Zhang XY, Chen Z, et al. Orexin prevents depressive-like behavior by promoting stress resilience. Mol Psychiatry. 2019;24(2):282-293. https://doi.org/10.1038/s41380-018-0127-0.

5. Perekrest SV, Shainidze KZ, Loskutov YuV, et al. Immunoreactivity of orexin-containing business in the level of expression of the preproorexin gene in these cells after administration of lipopolysaccharide. Neuroscience and Behavioral Physiology. 2013;43(2):256-260. 